(2) Open Access Full Text Article

\title{
Genetic polymorphisms of CASR and cancer risk: evidence from meta-analysis and HuGE review
}

This article was published in the following Dove Press journal:

OncoTargets and Therapy

9 February 2016

Number of times this article has been viewed

\section{Sohyun Jeong Jae Hyun Kim Myeong Gyu Kim \\ Nayoung Han \\ In-Wha Kim \\ Therasa Kim \\ Jung $\mathrm{MiOh}$}

College of Pharmacy and Research Institute of Pharmaceutical Sciences, Seoul National University, Seoul, South Korea
Correspondence: Jung Mi Oh

College of Pharmacy and Research Institute of Pharmaceutical Sciences, Seoul National University, I Gwanak-ro, Gwanak-gu, Seoul 08826, South Korea Tel +8228807997

Fax +8227669560

Email jmoh@snu.ac.kr
Background: $C A S R$ gene appears to be involved in cancer biology and physiology. However, a number of studies investigating $C A S R$ polymorphisms and cancer risks have presented inconclusive results. Thus, a systematic review and a meta-analysis of the effect of CASR polymorphisms on several cancer risks were performed to suggest a statistical evidence for the association of CASR polymorphisms with cancer risks.

Methods: MEDLINE, EMBASE, Web of Science, Scopus, and the HuGE databases were searched. Nineteen articles of case-control and cohort studies were included for the final analysis.

Results: The colorectal cancer risk was reduced in proximal (odds ratio $[\mathrm{OR}]=0.679, P=0.001$ ) and distal $(\mathrm{OR}=0.753, P=0.026)$ colon sites with GG genotype of $C A S R$ rs 1042636 and increased in distal colon site $(\mathrm{OR}=1.418, P=0.039)$ with $\mathrm{GG}$ genotype of $\mathrm{rs} 1801726$ by additive genetic model. The rs17251221 demonstrated noticeable associations that carrying a homozygote variant increases breast and prostate cancer risk considerably.

Conclusion: The significant association of CASR polymorphisms with several cancer risks was observed in this review. In particular, the act of CASR polymorphisms as a tumor suppressor or an oncogene differs by cancer site and can be the research target for tumorigenesis.

Keywords: rs1042636, rs1801725, rs1801726, systematic review, colorectal cancer

\section{Introduction}

The effect of calcium intake on various cancer risks is an ongoing topic of investigation. Besides the physiologic calcium level, the calcium-sensing receptor (CaSR), through which calcium balance is regulated, is thought to play an important role in the regulation of cancer expression. The activated CaSR can stimulate intracellular signal pathways including mitogen-activated protein kinase, phosphatidylinositol 3 kinase/ protein kinase B, and cy-mic and cyclin D1 pathways; these processes are involved in cellular secretion, proliferation, differentiation, chemotaxis, and apoptosis. ${ }^{1}$ The CaSR expression is related to the CASR gene that seems to have a role in cancer cells, acting both as a tumor suppressor and an oncogene, depending on the cancer site and environmental condition. In colonic epithelial cells, high calcium intake could reduce the risk of colorectal cancer development. ${ }^{2}$ E-cadherin stimulated by CaSR can interact with $\beta$-catenin, an important protooncogene, contribute to reducing the cancer cell activity, and downregulate cell proliferation. ${ }^{3}$ Whereas, the increased expression of $\mathrm{CaSR}$ by high calcium levels promoted $\mathrm{MCF}-7, \mathrm{PC}-3$, and $\mathrm{C} 4-2 \mathrm{~B}$ breast and prostate cancer cells known to metastasize to the bone and the cancer cell proliferation process is linked to extracellular signal-regulated kinases 1 and 2 (ERK 1/2) phosphorylation. ${ }^{4}$

The CASR gene contains seven exons and is located on chromosome $3 \mathrm{q} 13$. Among the single-nucleotide polymorphisms (SNPs) in the CASR gene, rs 1801725 
(A986S, 2956G > T) causes an amino acid change from alanine (A) to serine (S), and the $\mathrm{T}$ allele is associated with higher levels of serum calcium. ${ }^{5}$ The rs 1042636 (R990G, $2968 \mathrm{~A}>\mathrm{G}$ ) polymorphism causes an amino acid change from arginine (A) to glycine $(\mathrm{G})$ and induces a gain-offunction mutation associated with primary hyperparathyroidism and calcium stone formation. ${ }^{6-8}$ The rs 1801726 (Q1101E, 3403C $>\mathrm{G}$ ) is a common polymorphism in African ethnicity whose functional characteristics need further investigation; ${ }^{910}$ glutamine $(\mathrm{Q})$ to glutamic acid (A) change is observed.

The rs17251221 (1378-1412A $>\mathrm{G})$ in introns, which is in high linkage disequilibrium with rs $1801725,{ }^{11}$ induces a gain-of-function mutation associated with total serum calcium concentration ${ }^{11}$ and stone multiplicity in patients with nephrolithiasis. ${ }^{12}$

Recently, many studies have focused on the association between CASR gene polymorphism and multiple cancer risks. Three common nonsynonymous SNPs (rs1801725, rs1042636, and rs1801726) have been the primary research targets for cancer risk, but inconsistent results have been reported. Dong et $\mathrm{al}^{13}$ reported that $C A S R$ variants are not associated with colorectal cancer risk, whereas Jenab et al ${ }^{14}$ suggested possible association between CASR rs1042636 variations with colorectal cancer risk. Additional genetic variants of the large CASR gene (102 kb), which cannot be sufficiently explained by the three nonsynonymous SNPs, are also the research targets of cancer risks. Thus, a systematic review on the effect of CASR polymorphisms with several cancer risks and a meta-analysis on colorectal cancer risk were performed to suggest statistical evidence for the clinical use of cancer markers.

\section{Methods}

\section{Search strategy and eligibility criteria}

The electronic databases of MEDLINE, EMBASE, Web of Science, Scopus, and the HuGE Published Literature database were searched with the following keywords: ("calcium sensing receptor" OR "casr protein" OR “CASR" OR "Calcium sensing receptor gene") AND ("cancers" OR "neoplasia"). The references of included articles were checked to include any additional relevant articles.

A systematic search for relevant literature was performed to include studies published up to July 26, 2014, by two independent reviewers (JS and KJ) without language restrictions. Any disagreement was resolved by discussion between the authors. Inclusion criteria for article selection were as follows: 1) case-control studies or cohort studies and 2) sufficient data reporting odds ratio (OR) with $95 \%$ confidence interval (CI) or sample frequency with which the appropriate calculations could be done. Studies were excluded if they were 1) duplicate or previously published, 2) letters, reviews, or editorials, and 3) CASR gene studies on cell lines or animals by PRISMA flow diagram.

\section{Data extraction}

The following information was extracted from included studies: first author, year of publication, country of study site, ethnic group, genotyping method, number of genotyped cases and controls, genotype frequencies for cases and controls, selection pool of control population (population-based controls and hospital-based controls) and Hardy-Weinberg equilibrium (HWE) in any population, tumor type and site, OR, and corresponding 95\% CI. Ethnicity was classified as Caucasian, Asian, or African. When the study did not specify the ethnicity, the term "mixed ethnicity" was used. Any discrepancies in the extracted information were resolved by discussion among the authors.

\section{Quality score assessment}

Two reviewers (JS and KJ) independently evaluated the quality of the selected studies using the quality assessment scoring tool developed for genetic association studies by Thakkinstian et al, ${ }^{15}$ which was modified from previous metaanalyses of observational studies ${ }^{16-19}$ considering traditional epidemiologic and genetic issues ${ }^{20,21}$ (Table S1).

\section{Statistical analysis}

The association of three nonsynonymous CASR SNPs with colorectal cancer risk was examined by unconditional logistic regression to obtain ORs with 95\% CIs in additive, dominant, and recessive genetic models and represented by forest plot. The pooled ORs were calculated for each genetic model and different cancer sites (eg, proximal colon, distal colon). Whenever ORs and 95\% CIs were not reported, appropriate data were selected and calculated to produce OR with $95 \%$ CI. Between-study heterogeneity was assessed by the $Q$-statistic (heterogeneity was considered statistically significant if $P<0.1)^{22}$ and quantified by the $I^{2}$ value. Both fixed- and random-effects models were used to combine the aggregate data determined by the $I^{2}$ value. When $I^{2}$ was $>50 \%$, the random-effects model was used for analysis. Potential publication bias was assessed with the linear regression method of Egger's test ${ }^{23}$ and funnel plot. ${ }^{24}$ Statistical analyses were performed 
using Comprehensive Meta-Analysis (Version 2; Biostat, Inc., Engelwood, NJ, USA) and PASW (Version 21; IBM Corporation, Armonk, NY, USA). All tests were two-sided, and $P<0.05$ was considered significant unless otherwise specified.

\section{Results \\ Study selection}

Twenty out of 1,309 publications were found to be eligible for systematic review as shown in Figure $\mathrm{S} 1$.

Among eligible publications, the study by Speer et $\mathrm{al}^{25}$ was excluded due to an overlapping population with another study by the same author. ${ }^{26}$ Also, a study for esophageal cancer ${ }^{27}$ was excluded due to insufficient SNP information. By hand search, a study by Mahmoudi et $\mathrm{a}^{28}$ was added, and the final number of studies included for systematic review was 19 (Table 1).

In meta-analysis, two articles that reported colorectal cancer risk of rs 1801725 were excluded because the reported frequency of homozygote variants was 0 . Meta-analyses for colorectal cancer risk included 4,209 cases and 4,801 controls for rs 1801725 and 5,557 cases and 5,552 controls for rs1042636 and rs1801726, respectively.

\section{Synthesis of result by meta-analysis on the colorectal cancer risk}

The association between rs1801725, rs1042636, rs1801726 and colorectal cancer risk, stratified by genetic model and cancer site, is presented in Table 2.

Figures 1-3 demonstrate the pooled associations between three nonsynonymous $C A S R$ polymorphisms and colorectal cancer risk in forest plot.

$\mathrm{T}$ allele polymorphisms of rs1801725 did not show any association with colorectal cancer risk compared with the wild-type homozygous GG genotype. With the additive genetic model (TT vs GG), the pooled OR was 1.152 (95\% CI: 0.859-1.543, $I^{2}: 25.769$ ) (Table 2, Figure 1).

The colorectal cancer risk was significantly reduced in GG genotype of rs1042636 compared with the wild type in both proximal and distal colon sites with additive genetic model (OR $=0.679$ [95\% CI: 0.536-0.859], $\left.I^{2}: 42.519\right)$ in proximal colon and $(\mathrm{OR}=0.753$ [95\% CI: 0.587-0.967], $\left.I^{2}: 0\right)$ in distal colon. With the dominant genetic model, the association was not significant (Table 2, Figure 2). GG genotype of rs1801726 showed increased colorectal cancer risk in the distal colon site with additive genetic model (OR $=1.418$ [95\% CI: 1.017-1.977], $I^{2}$ : 0) (Table 2, Figure 3).
Systematic reviews of the association of CASR polymorphisms with cancer risks

From 19 studies that reported CASR polymorphisms and cancer risks, we extracted significant SNPs associated with several cancer risks that could not be assessed by metaanalysis for future research targets stratified by cancer type and cancer site (Table 3).

\section{CASR SNPs}

Having a $\mathrm{T}$ allele of rs 1801725 is associated with clinical stage $4(P=0.002)$ and the histological subgroup of undifferentiated neuroblastomas $(P=0.046) .{ }^{29}$ Patients with this polymorphism had significantly lower overall survival rates $(P=0.022)$ and event-free survival rates $(P=0.01)$ than those who had GG homozygotes.

African-American prostate cancer patients having advanced disease were approximately six times less carrying the homozygote minor allele of rs1801726 than were controls $(P=0.01){ }^{30}$

The polymorphism of rs 17251221 demonstrated a noticeable association with prostate and breast cancer risk; carrying a homozygote variant increases the risk of breast and prostate cancer considerably. ${ }^{31,32}$

\section{Haplotype and diplotypes}

Colorectal adenoma risk was associated with diplotype (GAC/GAG) of rs1801725, rs1042636, and rs1801726 $\left(\mathrm{OR}=0.56\right.$ [95\% CI: 0.36-0.88]). ${ }^{33}$ The polymorphism of rs1801726 on this diplotype reduced distal colon adenoma risk by half compared with the diplotype only composed of wild types (GAC/GAC). The haplotype (CC) of rs4678174 and rs2270916 was associated with cancer risk compared with the wild-type haplotype (TT) in the proximal colon $\left(\mathrm{OR}=0.80\right.$ [95\% CI: 0.67-0.97]). ${ }^{13} \mathrm{TAC}$ haplotype of $C A S R$ rs1801725, rs1042636, and rs1801726 was compared with the wild-type GAC haplotype, and the increased incidence of stage 4 neuroblastoma (OR $=5.52$ [95\% CI: 1.78-17.18]) and inferior overall survival (hazard ratio $=2.74$ [95\% CI: $1.20-6.25]$ ) was reported with TAC haplotype. ${ }^{29}$

\section{Diet effects and CASR polymorphisms}

The polymorphisms of rs2270916, rs 10934578, rs12485716, and rs4678174 were not associated with colorectal cancer risk ${ }^{34}$ however, with low calcium intake, the genetic association was significant. This correlation was also valid in a study for prostate cancer; ${ }^{35}$ several SNPs were significant only under low calcium levels or low plasma vitamin D levels. 


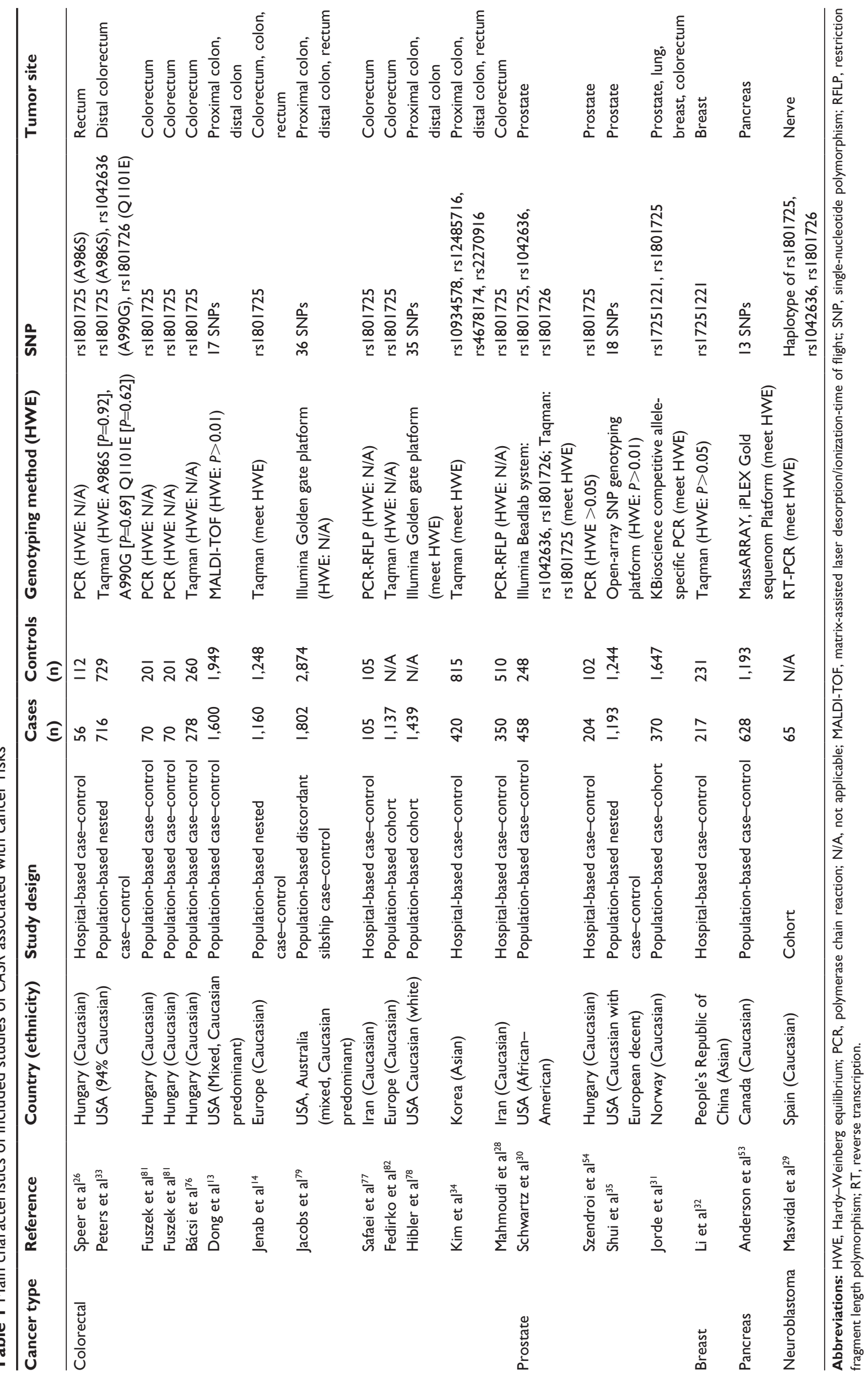


Table 2 Stratified analysis of the three nonsynonymous SNPs (rs I80I725, rs I042636, rs I80I726) in CASR and colorectal cancer risk by three genetic models and cancer sites

\begin{tabular}{|c|c|c|c|c|c|c|c|c|c|c|c|}
\hline \multicolumn{2}{|l|}{ Variable } & \multirow[t]{2}{*}{$\mathbf{N}^{*}$} & \multirow[t]{2}{*}{ n (case/control) } & \multicolumn{3}{|c|}{ Association } & \multicolumn{3}{|c|}{ Heterogeneity } & \multicolumn{2}{|c|}{ Publication bias } \\
\hline $\begin{array}{l}\text { Genetic } \\
\text { model }\end{array}$ & Site & & & OR & $95 \% \mathrm{Cl}$ & $P$-value & $I^{2}$ & $\begin{array}{l}P(Q)- \\
\text { value }\end{array}$ & Model & $\begin{array}{l}\text { Funnel } \\
\text { plot }\end{array}$ & $\begin{array}{l}\text { Egger's } \\
P \text {-value }\end{array}$ \\
\hline \multicolumn{12}{|l|}{ rs1801725 } \\
\hline TT vs GG & Colorectal & 6 & $4,209 / 4,801$ & 1.152 & $0.859-1.543$ & 0.379 & 25.769 & 0.345 & Fixed & None & 0.181 \\
\hline \multicolumn{12}{|l|}{ rsI042636 } \\
\hline \multirow[t]{2}{*}{ GG vs $A A$} & Proximal & 3 & $4,84 I / 4,823$ & 0.679 & $0.536-0.859$ & $0.001 * *$ & 42.519 & 0.176 & Fixed & None & 0.634 \\
\hline & Distal & 4 & $5,557 / 5,552$ & 0.753 & $0.587-0.967$ & $0.026 * *$ & 0 & 0.396 & Fixed & None & 0.957 \\
\hline \multirow[t]{2}{*}{$A G+G G$ vs $A A$} & Proximal & 3 & $4,84 I / 4,823$ & 0.797 & $0.505-1.260$ & 0.332 & 83.839 & 0.002 & Random & None & 0.175 \\
\hline & Distal & 3 & $4,84 \mathrm{I} / 4,823$ & 0.854 & $0.710-1.029$ & 0.097 & 44.491 & 0.165 & Fixed & None & 0.451 \\
\hline \multicolumn{12}{|l|}{ rsI80I726 } \\
\hline \multirow[t]{2}{*}{ GG vs CC } & Proximal & 3 & $4,84 I / 4,823$ & 1.137 & $0.820-1.575$ & $0.44 I$ & 0 & 0.408 & Fixed & None & 0.601 \\
\hline & Distal & 4 & $5,557 / 5,552$ & 1.418 & $1.017-1.977$ & $0.039 * *$ & 0 & 0.676 & Fixed & None & 0.770 \\
\hline \multirow[t]{2}{*}{$C G+G G$ vs $C C$} & Proximal & 3 & $4,84 \mathrm{I} / 4,823$ & 1.095 & $0.882-1.360$ & 0.411 & 0 & $0.48 I$ & Fixed & None & 0.987 \\
\hline & Distal & 3 & $4,84 I / 4,823$ & 1.073 & $0.857-1.344$ & 0.537 & 59.415 & 0.085 & Random & None & 0.414 \\
\hline
\end{tabular}

Notes: *Number of studies included in the meta-analysis. **Significant result.

Abbreviations: SNP, single-nucleotide polymorphism; OR, odds ratio; $\mathrm{Cl}$, confidence interval.

\section{Quality score assessment}

The quality score of each study was graded: 13 studies were graded 8 and over and six studies were under 8 (Table S2), and overall included studies are well designed: 13 studies have over 500 research subjects and 12 studies have population-based recruiting methods.

\section{Publication bias}

As a widely accepted tool for publication bias, Egger's linear regression methods and funnel plot were used. Overall, Egger's linear regression methods and funnel plots in rs1801725, rs1042636, and rs1801726 polymorphisms did not detect publication bias (Table 2, Figures 1-3).

\section{Discussion}

In this review, we presented the novel findings of significant association between CASR rs1042636, rs1801726, and rs17251221 polymorphisms; rs 1042636 decreased the colorectal cancer risk in proximal and distal sites, but rs 1801726 increased the risk in distal colon site. The rs17251221 considerably increased the cancer risk in prostate and breast. The CASR encodes a polypeptide of 1,078 amino acids with seven membrane spanning helixes characteristic of $G$ protein-coupled receptors (GPCRs). ${ }^{36,37}$ GPCRs have been known to have a direct link with cellular transformation with the discovery of MAS oncogene. ${ }^{38}$ Wild-type GPCRs could become oncogenic by the excessive exposure to local or circulating agonists. ${ }^{39-41}$ The G protein-coupled CaSR, through which calcium mediates its carcinogenesis, has been implicated in parathyroid gland cancer. ${ }^{42} \mathrm{CaSR}$ is also distributed through the entire gastrointestinal tract ${ }^{43-46}$ and reacts to the calcium concentrations in the lumen of the colon as well as circulating concentrations. ${ }^{47,48}$ Evidence from several studies ${ }^{49-51}$ suggests that risk factors differ by site within the colorectum, and molecular and functional
Colorectal site with additive genetic model (TT vs GG)

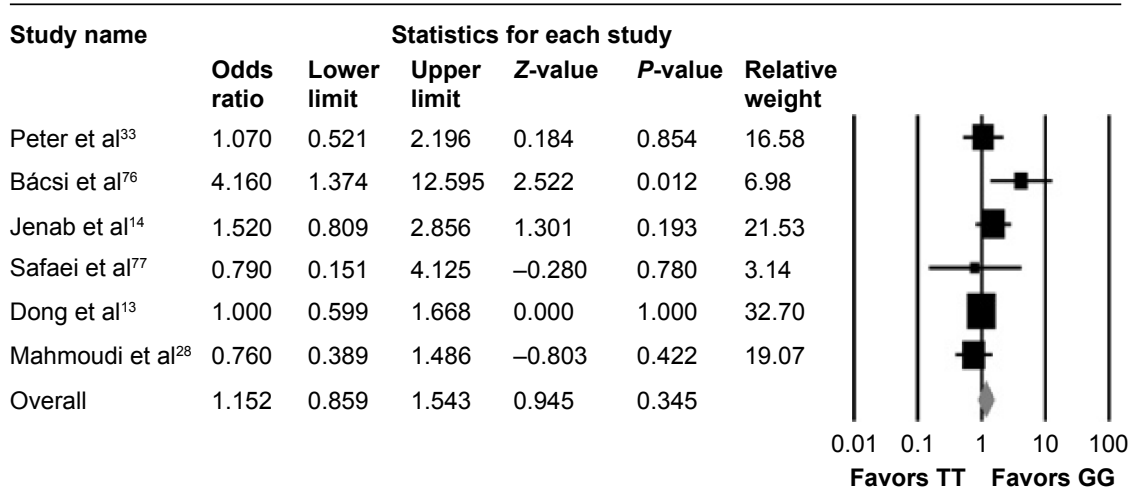

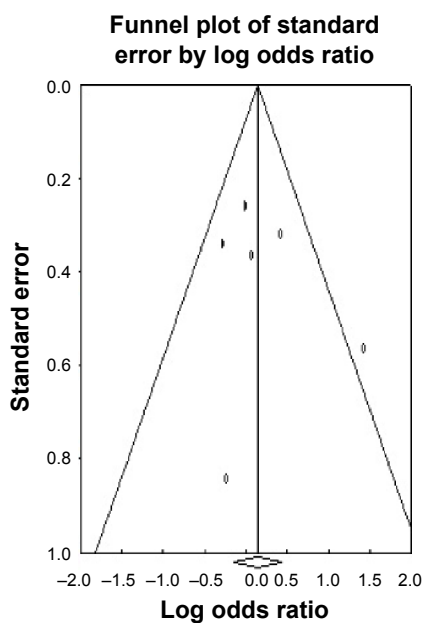

Figure I Association of rs 180 I 725 polymorphism with colorectal cancer risk by additive genetic model. 
Distal colon site with additive genetic model (GG vs. AA)

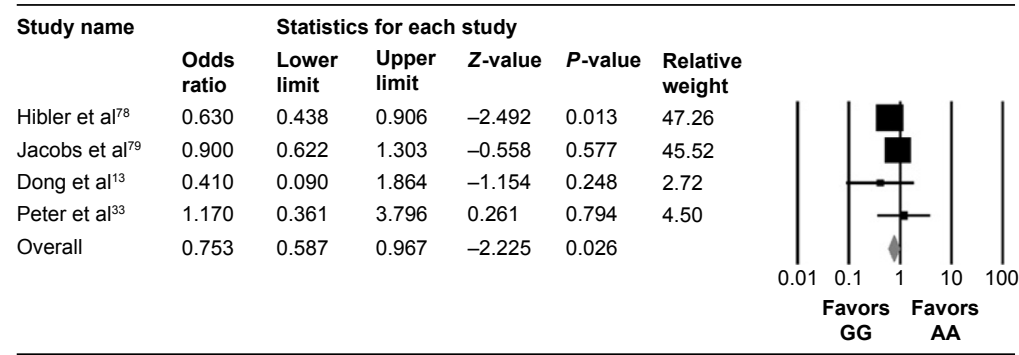

Distal colon site with dominant genetic model

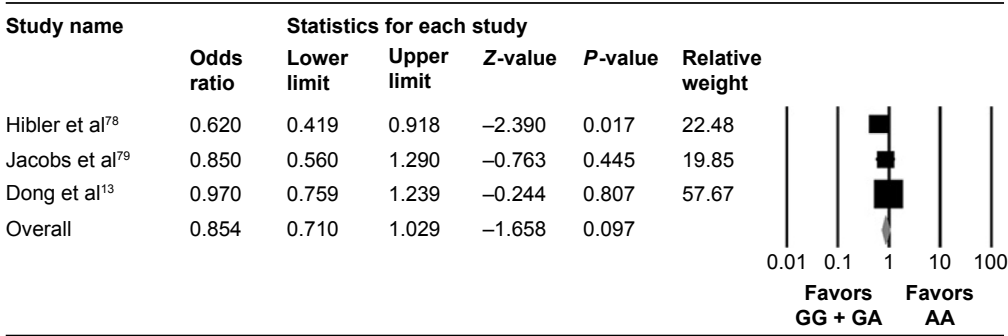

Proximal colon site with additive genetic model (GG vs. AA)

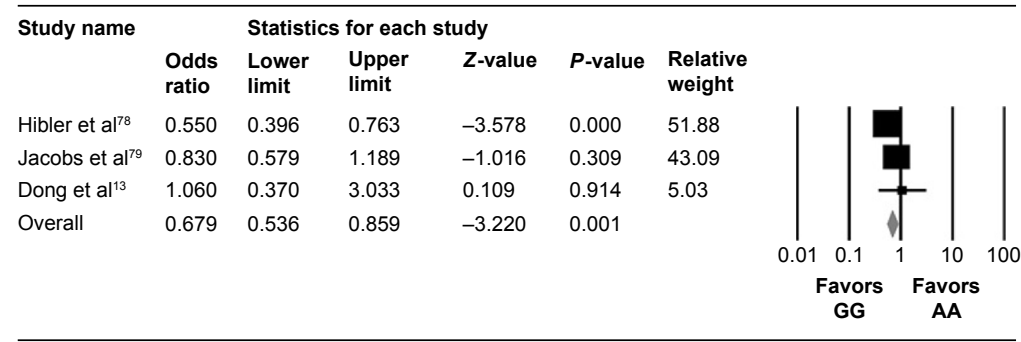

Proximal colon site with dominant genetic model

\begin{tabular}{|c|c|c|c|c|c|c|c|}
\hline \multirow[t]{2}{*}{ Study name } & \multicolumn{6}{|c|}{ Statistics for each study } & \\
\hline & $\begin{array}{l}\text { Odds } \\
\text { ratio }\end{array}$ & $\begin{array}{l}\text { Lower } \\
\text { limit }\end{array}$ & $\begin{array}{l}\text { Upper } \\
\text { limit }\end{array}$ & Z-value & $P$-value & $\begin{array}{l}\text { Relative } \\
\text { weight }\end{array}$ & \\
\hline Hibler et al ${ }^{78}$ & 0.510 & 0.358 & 0.726 & -3.734 & 0.000 & 23.95 & v \\
\hline Jacobs et al ${ }^{79}$ & 0.880 & 0.602 & 1.285 & -0.661 & 0.508 & 20.85 & \\
\hline Dong et $\mathrm{al}^{13}$ & 1.090 & 0.864 & 1.376 & 0.725 & 0.468 & 55.20 & \\
\hline \multirow[t]{3}{*}{ Overall } & 0.869 & 0.731 & 1.033 & -1.590 & 0.112 & & \\
\hline & & & & & & & $\begin{array}{lllll}0.01 & 0.1 & 1 & 10 & 100\end{array}$ \\
\hline & & & & & & & $\begin{array}{cc}\text { Favors } & \text { Favors } \\
\text { GG + GA } & \text { AA }\end{array}$ \\
\hline
\end{tabular}
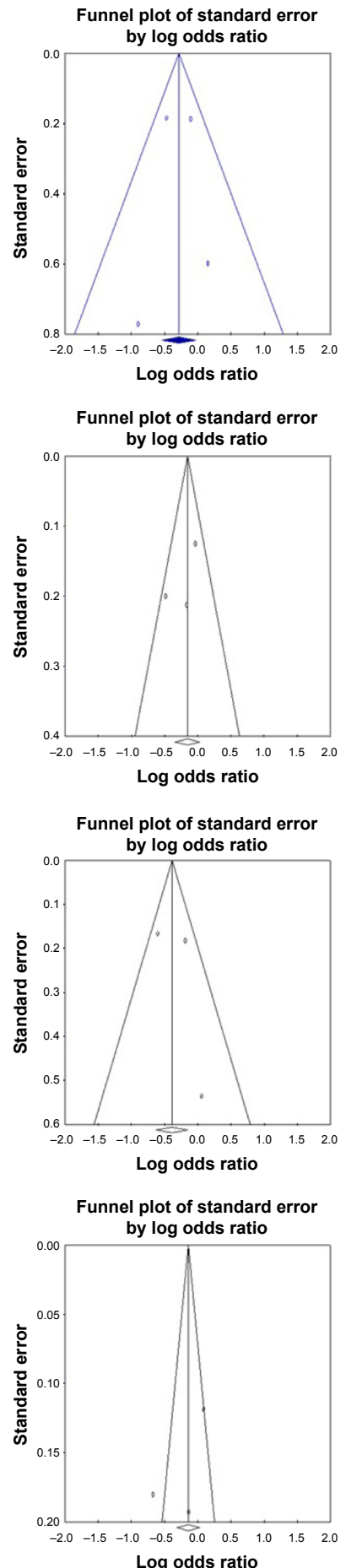

Figure 2 Association of rs 1042636 polymorphism with colorectal cancer risk stratified by cancer sites and three genetic models.

differences result in different susceptibility to exposures and environment, such as diet. Thus, colorectal cancer risk was analyzed by proximal and distal colon sites in our research.

The CASR gene carries three common nonsynonymous SNPs, each expressed at a much different allele frequency in three ethnic populations: rs1801725 (A986S) in Europeans (minor allele frequency: 13.3\%), rs1042636 (R990G) in
Asians (minor allele frequency: 50.4\%), and rs1801726 (Q1011E) in Africans (minor allele frequency: 23.3\%). ${ }^{52}$

The most frequent SNP in the Caucasian ethnicity, rs1801725, did not show any association with colorectal cancer risk. This finding is consistent with studies included in this systematic review on pancreatic ${ }^{53}$ and prostate cancers ${ }^{35,54}$ in Caucasians. The functional significance of this variant is small 
Distal colon site with additive genetic model (GG vs. CC)

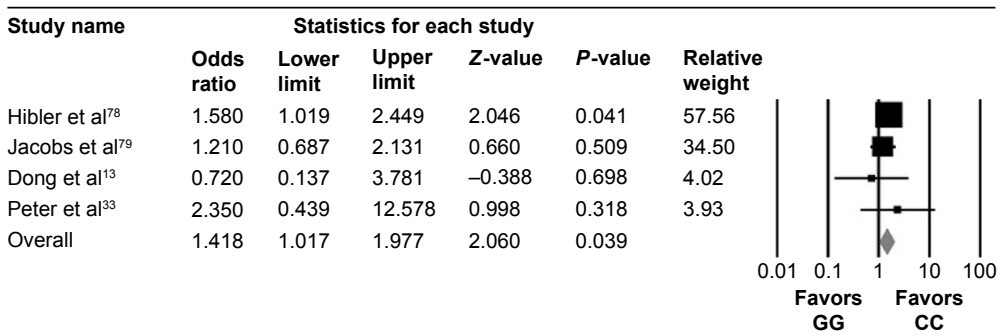

Distal colon site with dominant genetic model

\begin{tabular}{|c|c|c|c|c|c|c|}
\hline \multirow[t]{2}{*}{ Study name } & \multicolumn{5}{|c|}{ Statistics for each study } & \multirow[b]{2}{*}{$\begin{array}{l}\text { Relative } \\
\text { weight }\end{array}$} \\
\hline & $\begin{array}{l}\text { Odds } \\
\text { ratio }\end{array}$ & $\begin{array}{l}\text { Lower } \\
\text { limit }\end{array}$ & $\begin{array}{l}\text { Upper } \\
\text { limit }\end{array}$ & Z-value & $P$-value & \\
\hline Hibler et al ${ }^{78}$ & 1.590 & 1.011 & 2.502 & 2.006 & 0.045 & 24.63 \\
\hline Jacobs et $\mathrm{al}^{79}$ & 1.240 & 0.699 & 2.198 & 0.736 & 0.462 & 15.43 \\
\hline Dong et $\mathrm{al}^{13}$ & 0.880 & 0.658 & 1.177 & -0.862 & -0.388 & 59.94 \\
\hline Overall & 1.073 & 0.857 & 1.344 & 0.617 & 0.537 & \\
\hline
\end{tabular}

Proximal colon site with additive genetic model (GG vs. CC)

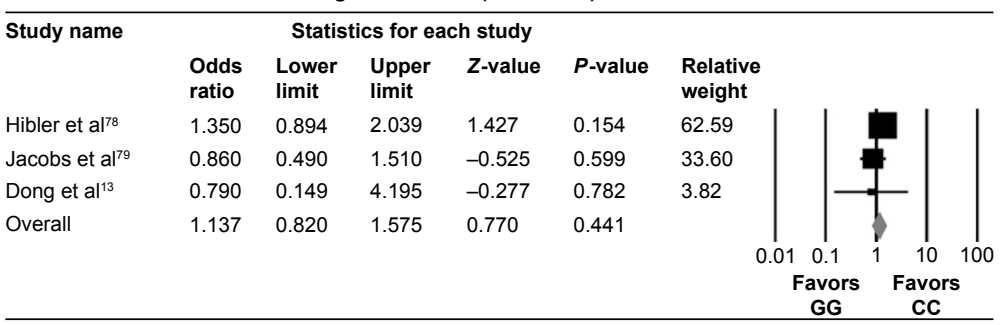

Proximal colon site with dominant genetic model

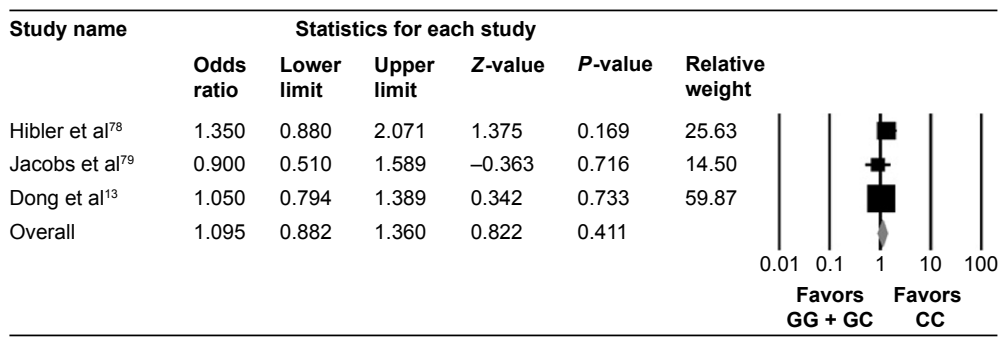
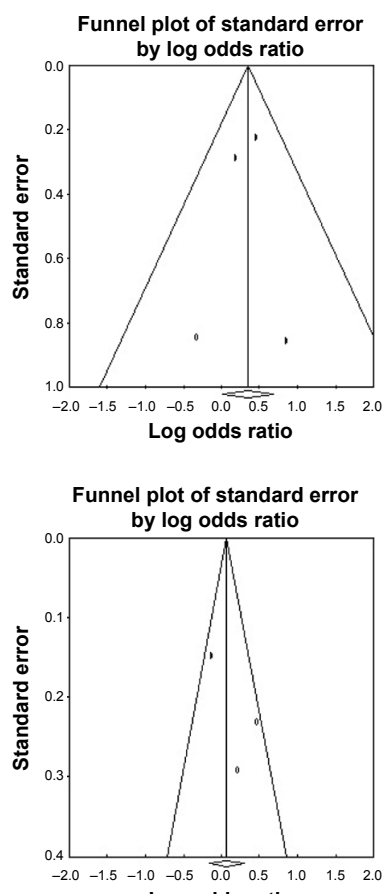

Log odds ratio
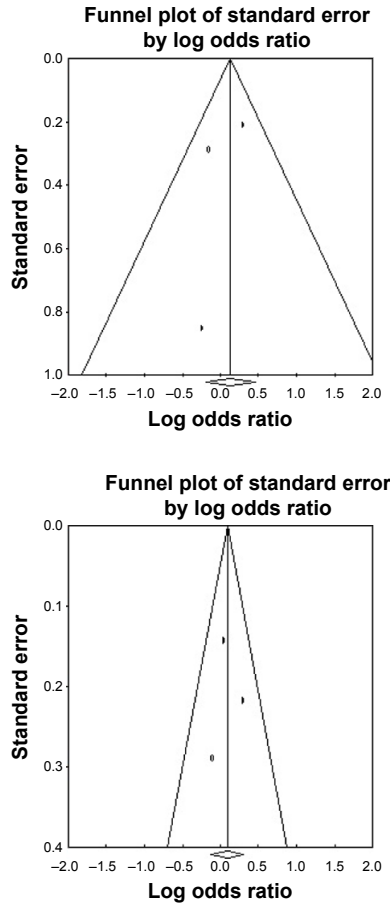

Figure 3 Association of rs 1801726 polymorphism with colorectal cancer risk stratified by cancer sites and three genetic models.

by amino acid substitution, ${ }^{55,56}$ such that the outcome of cancer risk could be negligible. ${ }^{13}$ The study of Masvidal et al ${ }^{29}$ is the only one to demonstrate that having a T allele of rs 1801725 is associated with later stage with significantly low overall and event-free survival in patients with neuroblastoma.

The rs1042636 (R990G) variant, which is frequently found in the Asian population, seems functionally relevant, as evidenced by cross-species evolutionary conservation. ${ }^{57}$ Based on physical properties, the change from positively charged arginine (R) to hydrophilic glycine $(\mathrm{G})$ at codon 990 results in different functionality. ${ }^{58}$ This property is consistent with the results of this meta-analysis that GG genotype showed a decreased cancer risk by $25 \%$ compared to the wild-type AA genotype in the distal colon and by $32 \%$ in the proximal colon. 


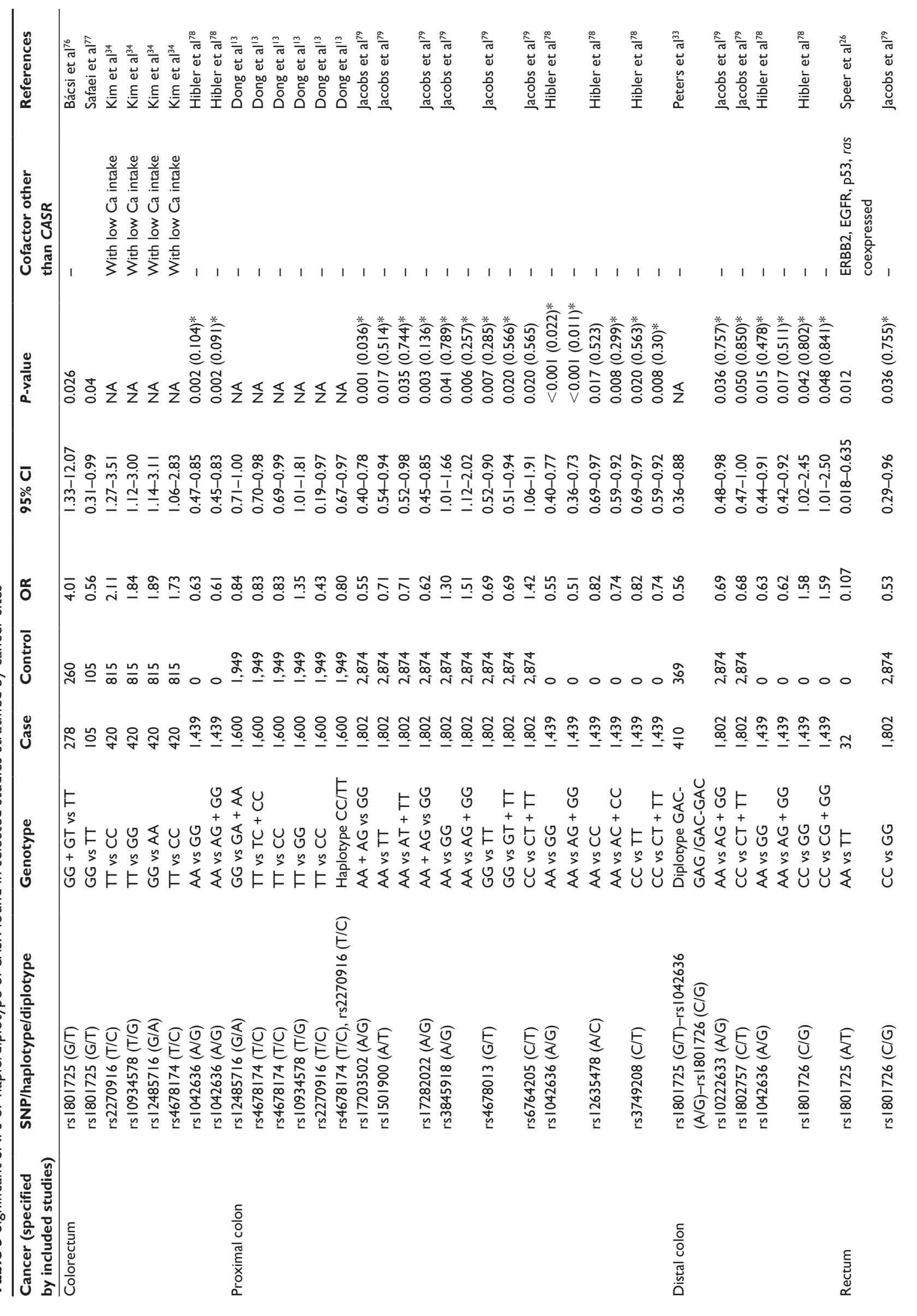




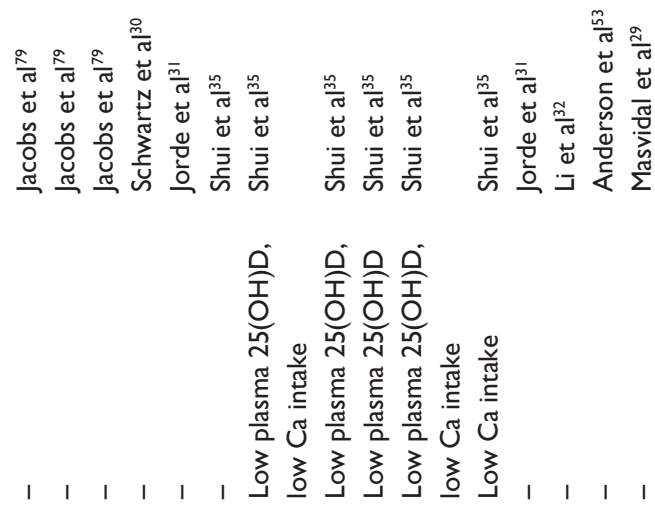

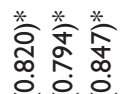

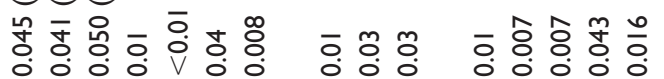

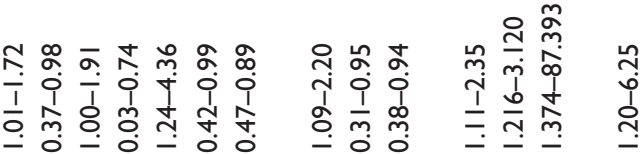

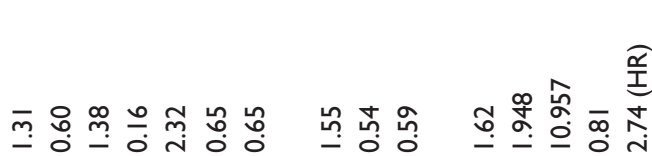

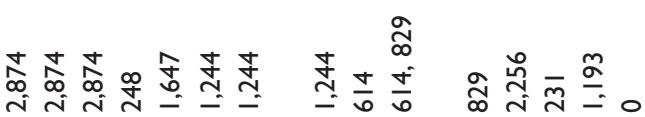

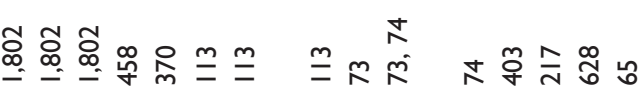

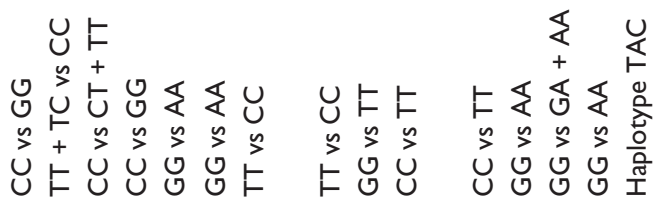

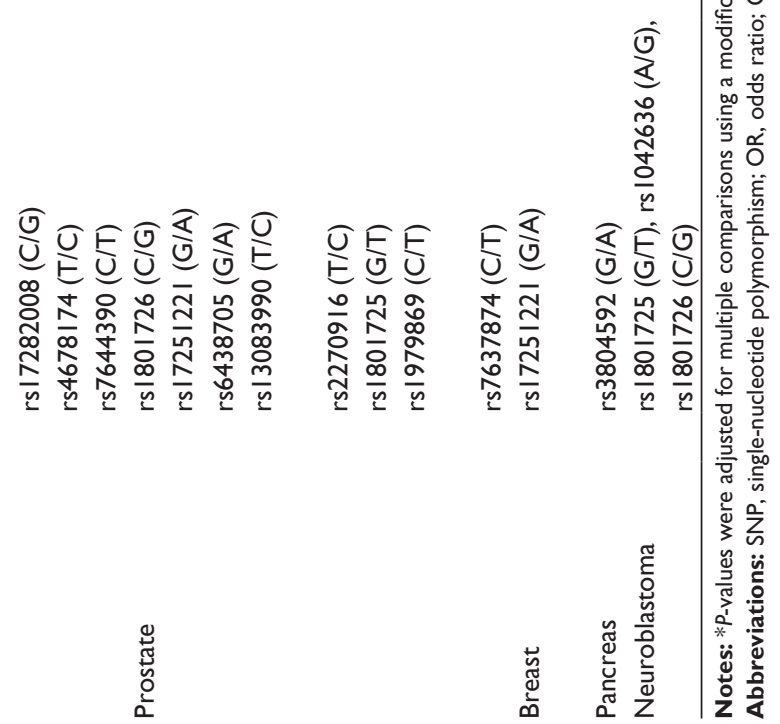

According to a report by the Center for Disease Control in 2011, Africans had the highest rate of colorectal cancer, followed by Caucasian, Hispanic, Asian/Pacific Islander, and American Indian/Alaska Native..$^{59,60}$ The results of our study that represent decreasing cancer risk by variant rs 1042636 (high frequency in Asian) and increasing cancer risk by variant rs1801726 (high frequency in African) might explain part of the colorectal cancer risk by genetic causality.

One of the major risk factors of colorectal cancer is diet. ${ }^{61}$ Specifically, calcium and dairy product intake have been studied, and high calcium intake is associated with decreased colorectal cancer risk. ${ }^{62-67}$ According to the study by Kim et $\mathrm{al}^{34}$ on colorectal cancer and Shui et a $\mathrm{a}^{35}$ on prostate cancer, several SNPs are significant only under low calcium intake or low plasma vitamin D level and that SNPs of CASR are under strong influence of epigenetic factors and regulation of calcium and vitamin $D$ intake is a vital factor in tumorigenesis. In fact, methylation of CASR was shown in $69 \%$ of colorectal cancer tissues and $90 \%$ of lymph node metastatic tissues and was strongly associated with reduced CaSR expression. ${ }^{68}$ Both prostate and breast cancers of high mortality are strongly related to bone metastasis. ${ }^{69}$ Approximately $75 \%$ of patients who develop advanced breast cancer will have secondary tumors in the bone, while in the case of prostate cancer, $\sim 90 \%$ of patients who die of advanced prostate cancer develop bone metastases. ${ }^{70,71}$ Overexpression of CaSR can serve as a major target of calcium in facilitating the formation and growth of skeletal metastasis of prostate and breast cancers.

One of the important aspects of CaSR research is that CaSR is highly correlated with the response of chemotherapeutics. CaSR signaling regulates the expression of thymidylate synthase and survivin and facilitates 5-fluorouracil treatment, which is one of the drugs of choice in colon cancer chemotherapy. ${ }^{72,73}$ The treatment of paclitaxel, a mitotic inhibitor used in chemotherapy is also related with CaSR. Knocking down the tumor suppressor gene $B R A C 1$ leads to a downregulation of CaSR expression and results in upregulation of survivin which reduced the cancer cell's sensitivity. ${ }^{74}$

Therefore, CASR gene polymorphisms can be the research target for the cancer causality and improvement of chemotherapeutics.

The limitations of this study should be acknowledged. First, most of the studies were mainly on colorectal cancers in Caucasians, ethnic factors could not be evaluated in the meta-analysis. Second, the total number of cases and controls is $\sim 10,000$, which is not enough for a meta-analysis of genetic association study under Venice guidelines ${ }^{75}$ to elucidate robust evidence. Third, several studies were performed under 
hospital-based control population, which could modulate population characteristics by selection bias.

\section{Conclusion}

In summary, CASR polymorphisms are highly associated with cancer risks in various sites. The evaluation of $C A S R$ in clinical aspect as a cancer biomarker and in therapeutics should consider the ethnicity, environment and diet effects concomitantly. Further research stratified by cancer site, environmental impact, and ethnicity should be undertaken.

\section{Acknowledgment}

This research was supported by Basic Science Research Program (2014R1A1A2055734) and ICT \& Future Planning (2014M3C1B3064644) through the National Research Foundation of Korea (NRF) funded by the Ministry of Education and Brain Korea 21 Plus Program in 2014.

\section{Disclosure}

The authors report no conflicts of interest in this work.

\section{References}

1. Brennan S, Conigrave A. Regulation of cellular signal transduction pathways by the extracellular calcium-sensing receptor. Curr Pharm Biotechnol. 2009;10:270-281.

2. Lamprecht S, Lipkin M. Cellular mechanisms of calcium and vitamin D in the inhibition of colorectal carcinogenesis. Ann N Y Acad Sci. 2001; 952:73-87.

3. Brembeck F, Rosario M, Birchmeier W. Balancing cell adhesion and Wnt signaling, the key role of beta-catenin. Curr Opin Genet Dev. 2006; 16:51-59.

4. Hiani YE, Lehen'kyi V, Ouadid-Ahidouch H, et al. Activation of the calcium-sensing receptor by high calcium induced breast cancer cell proliferation and TRPC1 cation channel over-expression potentially through EGFR pathways. Arch Biochem Biophys. 2009;486:58-63.

5. Kapur K, Johnson T, Beckmann ND, et al. Genome-Wide MetaAnalysis for Serum Calcium Identifies Significantly Associated SNPs near the Calcium-Sensing Receptor (CASR) Gene. Plos genetics. 2010; 6(7):1-12

6. Yamauchi M, Sugimoto T, Yamaguchi T, et al. Association of polymorphic alleles of the calcium-sensing receptor gene with the clinical severity of primary hyperparathyroidism. Clin Endocrinol (Oxf). 2001; 55(3):373-379.

7. Corbetta S, Eller-Vainicher C, Filopanti M, et al. R990G polymorphism of the calcium-sensing receptor and renal calcium excretion in patients with primary hyperparathyroidism. Eur J Endocrinol. 2006; 155(5):687-692.

8. Scillitani A, Guarnieri V, Battista C, et al. Primary hyperparathyroidism and the presence of kidney stones are associated with different haplotypes of the calcium-sensing receptor. J Clin Endocrinol Metab. 2007; 92(1):277-283.

9. Hu J, Spiegel AM. Structure and function of the human calcium-sensing receptor: insights from natural and engineered mutations and allosteric modulators. J Cell Mol Med. 2007;11(5):908-922.

10. Yun FH, Wong BY, Chase M, et al. Genetic variation at the calciumsensing receptor (CASR) locus: implications for clinical molecular diagnostics. Clin Biochem. 2007;40(8):551-561.

11. O'Seaghdha CM, Wu H, Yang Q, et al. Meta-analysis of genomewide association studies identifies six new Loci for serum calcium concentrations. Plos genetics. 2013;9(9):1-13.
12. Chou YH, Woon PY, Chen WC, et al. A genetic polymorphism (rs17251221) in the calcium-sensing receptor gene (CASR) is associated with stone multiplicity in calcium nephrolithiasis. PLoS One. 2011;6(9):e25227.

13. Dong LM, Ulrich CM, Hsu L, et al. Genetic variation in calcium-sensing receptor and risk for colon cancer. Cancer Epidemiol Biomarkers Prev. 2008;17(10):2755-2765.

14. Jenab M, McKay J, Bueno-de-Mesquita HB, et al. Vitamin D receptor and calcium sensing receptor polymorphisms and the risk of colorectal cancer in European populations. Cancer Epidemiol Biomarkers Prev. 2009;18(9):2485-2491.

15. Thakkinstian AMM, Minelli C, Gibson P, et al. Systematic review and meta-analysis of the association between \{beta\}2-adrenoceptor polymorphisms and asthma: a HuGE review. Am J Epidemiol. 2005;162(3):201-211.

16. van Tulder MW, Assendelft WJ, Koes BW, et al. Spinal radiographic findings and nonspecific low back pain. A systematic review of observational studies. Spine. 1997;22(4):427-434.

17. Xu L, McElduff P, D'Este C, et al. Does dietary calcium have a protective effect on bone fractures in women? A meta-analysis of observational studies. Br J Nutr. 2004;91(04):625-634.

18. LeBlanc ES, Janowsky J, Chan BK, et al. Hormone replacement therapy and cognition: systematic review and meta-analysis. JAMA. 2001; 285(11):1489-1499.

19. Harris RP, Helfand M, Woolf SH, et al. Current methods of the US preventive services task force: a review of the process. Am J Prev Med. 2001;20(3 suppl):21-35.

20. Davey SG, Egger M. Meta-analyses of randomised controlled trials. Lancet. 1997;350(9085):1182.

21. Attia J, Thakkinstian A, D'Este C. Meta-analyses of molecular association studies: methodologic lessons for genetic epidemiology. J Clin Epidemiol. 2003;56(4):297-303.

22. Harbord RM, Egger M, Sterne JA. A modified test for small-study effects in meta-analyses of controlled trials with binary endpoints. Stat Med. 2006;25(20):3443-3457.

23. Egger M, Smith GD, Schneider M, et al. Bias in meta-analysis detected by a simple, graphical test. $\mathrm{Br}$ Med J. 1997;315(7109):629.

24. Sterne JAC, Sutton AJ, Ioannidis JPA, et al. Recommendations for examining and interpreting funnel plot asymmetry in meta-analyses of randomised controlled trials. BMJ. 2011;343:1-8.

25. Speer G, Cseh K, Fuszek P, et al. The role of estrogen receptor, vitamin $\mathrm{D}$ receptor and calcium receptor genotypes in the pathogenesis of colorectal cancer. Orv Hetil. 2001;142(18):947-951.

26. Speer G, Cseh K, Mucsi K, et al. Calcium-sensing receptor A986S polymorphism in human rectal cancer. Int J Colorectal Dis. 2002; 17(1):20-24.

27. Rao S, Welsh L, Cunningham D, et al. Correlation of overall survival with gene expression profiles in a prospective study of resectable esophageal cancer. Clin Colorectal Cancer. 2011;10(1): $48-56$.

28. Mahmoudi T, Karimi K, Arkani M, et al. Parathyroid hormone gene rs6256 and calcium sensing receptor gene rs 1801725 variants are not associated with susceptibility to colorectal cancer in Iran. Asian Pac J Cancer Prev. 2014;15(15):6035-6039.

29. Masvidal L, Iniesta R, Casala C, et al. Polymorphisms in the calciumsensing receptor gene are associated with clinical outcome of neuroblastoma. PLoS One. 2013;8(3):e59762.

30. Schwartz GG, John EM, Rowland G, et al. Prostate cancer in African-American men and polymorphism in the calcium-sensing receptor. Cancer Biol Ther. 2010;9(12):994-999.

31. Jorde R, Schirmer H, Njølstad I, et al. Serum calcium and the calciumsensing receptor polymorphism rs17251221 in relation to coronary heart disease, type 2 diabetes,cancer and mortality: the Tromsø Study. Eur J Epidemiol. 2013;28(7):569-578.

32. Li X, Kong X, Jiang L, et al. A Genetic Polymorphism (rs17251221) in the Calcium-Sensing Receptor is Associated with Breast Cancer Susceptibility and Prognosis. Cell Physiol Biochem. 2014;33(1): 165-172. 
33. Peters U, Chatterjee N, Yeager M, et al. Association of genetic variants in the calcium-sensing receptor with risk of colorectal adenoma. Cancer Epidemiol Biomarkers Prev. 2004;13(12):2181-2186.

34. Kim KZ, Shin A, Kim J, et al. Association between CASR polymorphisms, calcium intake, and colorectal cancer risk. PLoS One. 2013;8(3):e59628.

35. Shui IM, Mucci LA, Wilson KM, et al. Common genetic variation of the calcium-sensing receptor and lethal prostate cancer risk. Cancer Epidemiol Biomarkers Prev. 2013;22(1):118-126.

36. Aida K, Koishi S, Inoue M, et al. Familial hypocalciuric hypercalcemia associated with mutation in the human $\mathrm{Ca}(2+)$-sensing receptor gene. J Clin Endocrinol Metab. 1995;80(9):2594-2598.

37. Brown EM, Gamba G, Riccardi D, et al. Cloning and characterization of an extracellular $\mathrm{Ca}(2+)$-sensing receptor from bovine parathyroid. Nature. 1993;366(6455):575-580.

38. Young D, Waitches G, Birchmeier C, et al. Isolation and characterization of a new cellular oncogene encoding a protein with multiple potential transmembrane domains. Cell. 1986;45:711-719.

39. Dai Q, Shrubsole MJ, Ness RM, et al. The relation of magnesium and calcium intakes and a genetic polymorphism in the magnesium transporter to colorectal neoplasia risk. Am J Clin Nutr. 2007;86(3):743-751.

40. Gutkind JS, Novotny EA, Brann MR, et al. Muscarinic acetylcholine receptor subtypes as agonist-dependent oncogenes. Proc Natl Acad Sci US A. 1991;88(11):4703-4707.

41. Julius D, Livelli TJ, Jessell TM, et al. Ectopic expression of the serotonin 1c receptor and the triggering of malignant transformation. Science. 1989;244(4908):1057-1062.

42. Dorsam RT, Gutkind JS. G-protein-coupled receptors and cancer. Nat Rev Cancer. 2007;7(2):79-94.

43. Buchan AM, Squires PE, Ring M, et al. Mechanism of action of the calcium-sensing receptor in human antral gastrin cells. Gastroenterology. 2001;120(5):1128-1139.

44. Cheng SX, Okuda M, Hall AE, et al. Expression of calcium-sensing receptor in rat colonic epithelium: evidence for modulation of fluid secretion. Am J Physiol Gastrointest Liver Physiol. 2002;283(1): G240-G250.

45. Gama L, Baxendale-Cox LM, Breitwieser GE. Ca2+-sensing receptors in intestinal epithelium. Am J Physiol. 1997;273(4 pt 1):C1168-C1175.

46. Mitsuma T, Rhue N, Kayama M, et al. Distribution of calcium sensing receptor in rats: an immunohistochemical study. Endocr Regul. 1999; 33(2):55-59.

47. Chattopadhyay N, Cheng I, Rogers K, et al. Identification and localization of extracellular $\mathrm{Ca}(2+)$-sensing receptor in rat intestine. Am J Physiol. 1998;274(1 pt 1):G122-G130.

48. Lamprecht SA, Lipkin M. Chemoprevention of colon cancer by calcium, vitamin D and folate: molecular mechanisms. Nat Rev Cancer. 2003;3(8):601-614.

49. Bufill JA. Colorectal cancer: evidence for distinct genetic categories based on proximal or distal tumor location. Ann Intern Med 1990;113(10):779-788.

50. Iacopetta B. Are there two sides to colorectal cancer? Int J Cancer. 2002;101(5):403-408.

51. McMichael AJ, Potter JD. Host factors in carcinogenesis: certain bileacid metabolic profiles that selectively increase the risk of proximal colon cancer. J Natl Cancer Inst. 1985;75(2):185-191.

52. NCBI. dbSNP: Short Genetic Variation. 2015. Available from: http://www.ncbi.nlm.nih.gov/projects/SNP/snp_ref.cgi?rs=1801725. Accessed September 12, 2015

53. Anderson LN, Cotterchio M, Knight JA, et al. Genetic variants in vitamin d pathway genes and risk of pancreas cancer; results from a population-based case-control study in ontario, Canada. PLoS One. 2013;8(6):e66768.

54. Szendroi A, Speer G, Tabak A, et al. The role of vitamin D, estrogen, calcium sensing receptor genotypes and serum calcium in the pathogenesis of prostate cancer. Can J Urol. 2011;18(3):5710-5716.

55. Ng PC, Henikoff S. SIFT: predicting amino acid changes that affect protein function. Nucleic Acids Res. 2003;31(13):3812-3814.

56. Sunyaev S, Ramensky V, Koch I, et al. Prediction of deleterious human alleles. Hum Mol Genet. 2001;10(6):591-597.
57. Garrett JE, Capuano IV, Hammerland LG, et al. Molecular cloning and functional expression of human parathyroid calcium receptor cDNAs. J Biol Chem. 1995;270(21):12919-12925.

58. Miyata T, Miyazawa S, Yasunaga T. Two types of amino acid substitutions in protein evolution. J Mol Evol. 1979;12(3):219-236.

59. The Surveillance, Epidemiology and End Results Program as Submitted to the National Cancer Institute. 2013. Available from: http://www.cdc. gov/cancer/colorectal/statistics/race.htm. Accessed October 30, 2014.

60. National Program of Cancer Registries as Submitted to the National Cancer Institute. 2013. Available from: http://www.cdc.gov/cancer/ colorectal/statistics/race.htm. Accessed October 30, 2014.

61. Garland CF, Garland FC. Do sunlight and vitamin D reduce the likelihood of colon cancer? Int J Epidemiol. 2006;35(2):217-220.

62. Huncharek M, Muscat J, Kupelnick B. Colorectal cancer risk and dietary intake of calcium, vitamin D, and dairy products: a metaanalysis of 26,335 cases from 60 observational studies. Nutr Cancer. 2009;61(1):47-69.

63. Larsson SC, Bergkvist L, Rutegard J, et al. Calcium and dairy food intakes are inversely associated with colorectal cancer risk in the cohort of Swedish men. Am J Clin Nutr. 2006;83(3):667-673.

64. Park SY, Murphy SP, Wilkens LR, et al. Calcium and vitamin D intake and risk of colorectal cancer: the multiethnic cohort study. Am J Epidemiol. 2007;165(7):784-793.

65. Shin A, Li H, Shu XO, et al. Dietary intake of calcium, fiber and other micronutrients in relation to colorectal cancer risk: results from the Shanghai women's health study. Int J Cancer. 2006;119(12): 2938-2942.

66. Wu K, Willett WC, Fuchs CS, et al. Calcium intake and risk of colon cancer in women and men. J Natl Cancer Inst. 2002;94(6):437-446.

67. Cho E, Smith-Warner SA, Spiegelman D, et al. Dairy foods, calcium, and colorectal cancer: a pooled analysis of 10 cohort studies. J Natl Cancer Inst. 2004;96(13):1015-1022.

68. Hizaki K, Yamamoto $\mathrm{H}$, Taniguchi $\mathrm{H}$, et al. Epigenetic inactivation of calcium-sensing receptor in colorectal carcinogenesis. Mod Pathol. 2011;24(6):876-884.

69. Coleman RE. Skeletal complications of malignancy. Cancer. 1997; 80(8 suppl):1588-1594.

70. Roodman GD. Mechanisms of bone metastasis. Discov Med. 2004;4(22):144-148.

71. Liao J, Schneider A, Datta NS, et al. Extracellular calcium as a candidate mediator of prostate cancer skeletal metastasis. Cancer Res. 2006;66(18):9065-9073.

72. Liu G, Hu X, Chakrabarty S. Vitamin D mediates its action in human colon carcinoma cells in a calcium-sensing receptor-dependent manner: downregulates malignant cell behavior and the expression of thymidylate synthase and survivin and promotes cellular sensitivity to 5-FU. Int J Cancer. 2010;126:631-639.

73. Liu G, Hu X, Varani J, et al. Calcium and calcium sensing receptor modulates the expression of thymidylate synthase, NAD $(\mathrm{P}) \mathrm{H}$ :quinone oxidoreductase 1 and survivin in human colon carcinoma cells: promotion of cytotoxic response to mitomycin $\mathrm{C}$ and fluorouracil. Mol Carcinog. 2009;48(3):202-211.

74. Promkan M, Liu G, Patmasiriwat P, et al. BRCA1 suppresses the expression of survivin and promotes sensitivity to paclitaxel through the calcium sensing receptor (CaSR) in human breast cancer cells. Cell Calcium. 2011;49:79-88.

75. Ioannidis JP, Boffetta P, Little J, et al. Assessment of cumulative evidence on genetic associations: interim guidelines. Int J Epidemiol. 2008;37(1):120-132.

76. Bácsi K, Hitre E, Kósa JP, et al. Effects of the lactase 13910 C/T and calcium-sensor receptor A986S G/T gene polymorphisms on the incidence and recurrence of colorectal cancer in Hungarian population. BMC Cancer. 2008;8:317.

77. Safaei A, Arbabi-Aval E, Arkani M, et al. Association of Calciumsensing Receptor(CASR rs1801725) with Colorectal Cancer. Zahedan Journal of Research in Medical Sciences. 2012;14(7):45-48.

78. Hibler EA, Hu C, Jurutka PW, Martinez ME, Jacobs ET. Cancer Epidemiol Biomarkers Prev. 2012;21(2):368-375. 
79. Jacobs ET, Martínez ME, Campbell PT, et al. Genetic variation in the retinoid $\mathrm{X}$ receptor and calcium-sensing receptor, and risk of colorectal cancer in the Colon Cancer Family Registry. Carcinogenesis. 2010;31(8):1412-1416.

80. Conneely KN, Boehnke M. Meta-analysis of genetic association studies and adjustment for multiple testing of correlated SNPs and traits. Genet Epidemiol. 2010;34(7):739-746.
81. Fuszek P, Speer G, Nagy Z, Papp J, Lakatos PL, Lakatos P. Lack of association between the calcium-sensing receptor (CaSR) A986S polymorphism and colorectal cancer. Gastroenterology. 2003;124(4): A551-A552.

82. Fedirko V, Riboli E, Tjønneland A, et al. Cancer Epidemiol Biomarkers Prev. 2012;21(4):582-593. 


\section{Supplementary materials}

Table SI Methodological tool of quality assessment of individual studies included for CASR polymorphisms and cancer risk

Criteria

Quality score

Representativeness of cases

Consecutive/randomly selected from case population with clearly defined sampling frame

2

Consecutive/randomly selected from case population without clearly defined sampling frame or with extensive inclusion/exclusion criteria

No method of selection described

Representativeness of controls

Controls were consecutive/randomly drawn from the same sampling frame (ward/community) as cases 2

Controls were consecutive/randomly drawn from a different sampling frame as cases

Not described

Ascertainment of cancer diagnosis

Clearly described objective criteria for diagnosis of asthma

Diagnosis of asthma by patient self-report or by patient history

Not described

Ascertainment of controls

Controls were tested to screen out cancer

Controls were subjects who did not report cancer; no objective testing

Not described

Genotyping examination

Genotyping done under "blinded" condition

Unblinded or not mentioned

Hardy-Weinberg equilibrium

Hardy-Weinberg equilibrium in control group

Hardy-Weinberg disequilibrium in control group

No checking for Hardy-Weinberg equilibrium

Association assessment

Assess association between genotypes and cancers with appropriate statistics and adjustment for confounders

Assess association between genotypes and cancers with appropriate statistics without adjustment for confounders

Inappropriate statistics used
0

I

0

2

1

0

2

I

0

0

2

I

0

2

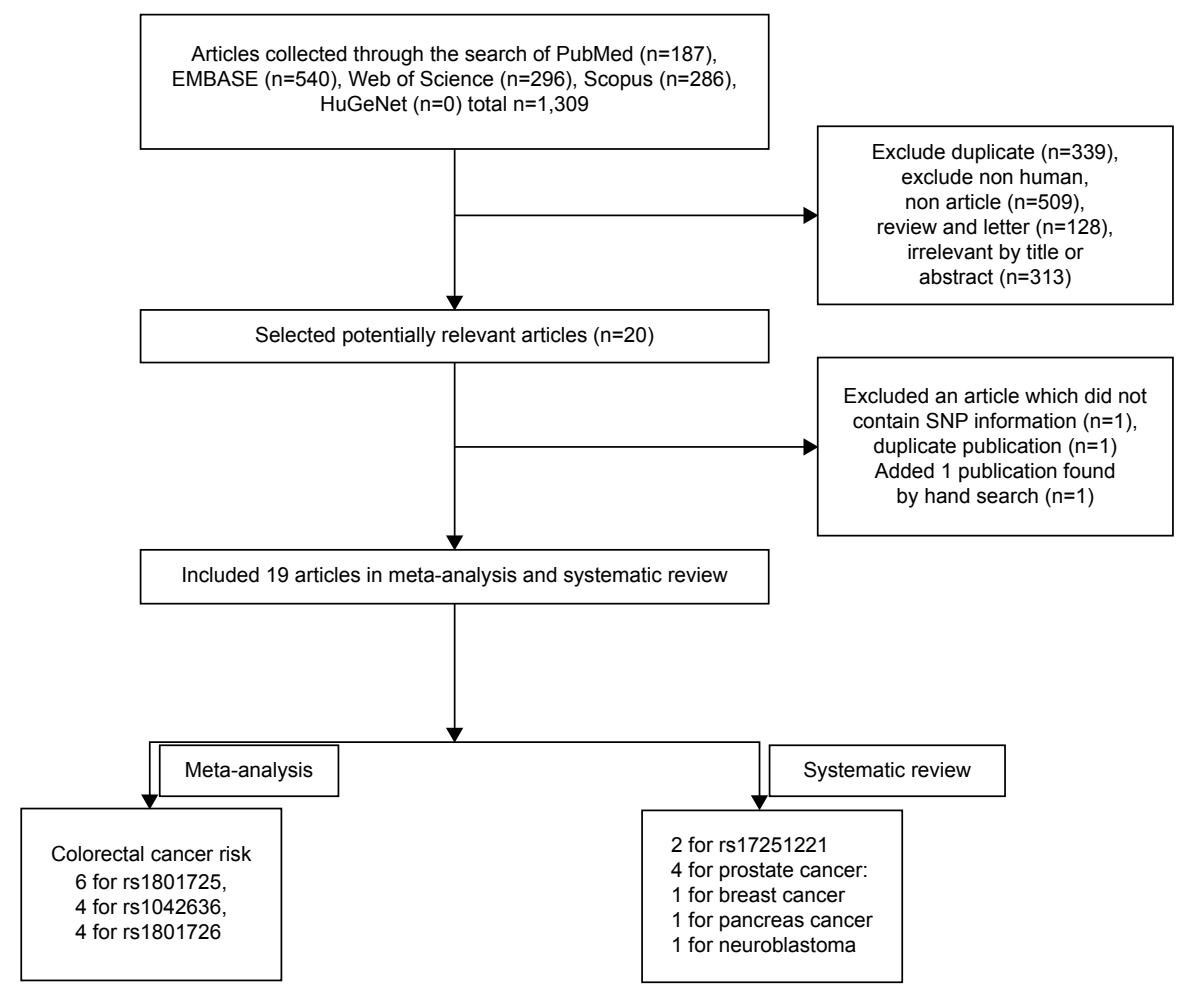

Figure SI The literature search and selection process by PRISMA flow diagram: 19 studies were included for meta-analysis and systematic review. Abbreviation: SNP, single-nucleotide polymorphism. 
Table S2 Results of comprehensive quality assessment of included studies for the meta-analysis and systematic review

\begin{tabular}{|c|c|c|c|c|c|c|c|c|}
\hline References & $\begin{array}{l}\text { Representativeness } \\
\text { of cases }\end{array}$ & $\begin{array}{l}\text { Representativeness } \\
\text { of controls }\end{array}$ & $\begin{array}{l}\text { Ascertainment } \\
\text { of cancer } \\
\text { diagnosis }\end{array}$ & $\begin{array}{l}\text { Ascertainment } \\
\text { of controls }\end{array}$ & $\begin{array}{l}\text { Genotyping } \\
\text { examination }\end{array}$ & HWE & $\begin{array}{l}\text { Association } \\
\text { assessment }\end{array}$ & $\begin{array}{l}\text { Total } \\
\text { score }\end{array}$ \\
\hline Speer et al' & 1 & 2 & 0 & I & 0 & 2 & 1 & 7 \\
\hline Peters et $\mathrm{al}^{2}$ & 2 & 2 & I & 2 & I & 2 & 2 & 12 \\
\hline Fuszek et $\mathrm{al}^{3}$ & 2 & I & I & 0 & 0 & 0 & I & 5 \\
\hline Bácsi et al ${ }^{4}$ & 2 & I & I & I & I & 2 & I & 9 \\
\hline Dong et $\mathrm{al}^{5}$ & 2 & 2 & I & I & I & 2 & 2 & 11 \\
\hline Jenab et $\mathrm{a}^{6}$ & 2 & 2 & I & I & I & 2 & 2 & 11 \\
\hline Jacobs et $\mathrm{al}^{7}$ & 2 & 2 & I & I & 0 & 0 & 2 & 8 \\
\hline Schwartz et $\mathrm{al}^{8}$ & 2 & 2 & I & 2 & I & 2 & 2 & 12 \\
\hline Szendroi et $\mathrm{al}^{9}$ & 2 & 2 & I & I & 0 & 2 & 2 & 10 \\
\hline Safaei et al ${ }^{10}$ & 2 & 2 & I & 2 & 0 & I & I & 9 \\
\hline Fedirko et al" & 2 & N/A & I & $\mathrm{N} / \mathrm{A}$ & 0 & 0 & 2 & 5 \\
\hline Shui et al ${ }^{12}$ & 2 & 2 & I & 2 & I & 2 & 2 & 12 \\
\hline Hibler et $\mathrm{al}^{13}$ & 2 & N/A & I & $N / A$ & 0 & 2 & 2 & 7 \\
\hline Anderson et $\mathrm{al}^{14}$ & 2 & 2 & I & I & 0 & 2 & 2 & 10 \\
\hline Kim et $\mathrm{al}^{15}$ & 2 & I & 0 & I & 0 & 2 & 1 & 7 \\
\hline Jorde et $\mathrm{al}^{16}$ & 2 & 2 & I & 2 & 0 & 2 & 2 & II \\
\hline Masvidal et al ${ }^{17}$ & 2 & N/A & I & $N / A$ & 0 & 2 & 1 & 6 \\
\hline Mahmoudi et al ${ }^{18}$ & 2 & 2 & I & 2 & 0 & 2 & 2 & 10 \\
\hline Li et al ${ }^{19}$ & 2 & I & I & 2 & 0 & 2 & 2 & 10 \\
\hline
\end{tabular}

Abbreviations: HWE, Hardy-Weinberg equilibrium; N/A, not applicable.

\section{References}

1. Speer G, Cseh K, Mucsi K, et al. Calcium-sensing receptor A986S polymorphism in human rectal cancer. Int $J$ Colorectal Dis. 2002;17(1):20-24.

2. Peters U, Chatterjee N, Yeager M, et al. Association of genetic variants in the calcium-sensing receptor with risk of colorectal adenoma. Cancer Epidemiol Biomarkers Prev. 2004;13(12):2181-2186.

3. Fuszek P, Speer G, Nagy Z, Papp J, Lakatos PL, Lakatos P. Lack of association between the calcium-sensing receptor (CaSR) A986S polymorphism and colorectal cancer. Gastroenterology. 2003;124(4): A551-A552.

4. Bácsi K, Hitre E, Kósa JP, et al. Effects of the lactase 13910 C/T and calcium-sensor receptor A986S G/T gene polymorphisms on the incidence and recurrence of colorectal cancer in Hungarian population. BMC Cancer. 2008;8:317.

5. Dong LM, Ulrich CM, Hsu L, et al. Genetic variation in calcium-sensing receptor and risk for colon cancer. Cancer Epidemiol Biomarkers Prev. 2008;17(10):2755-2765.

6. Jenab M, McKay J, Bueno-de-Mesquita HB, et al. Vitamin D receptor and calcium sensing receptor polymorphisms and the risk of colorectal cancer in European populations. Cancer Epidemiol Biomarkers Prev. 2009;18(9):2485-2491.

7. Jacobs ET, Martínez ME, Campbell PT, et al. Genetic variation in the retinoid $\mathrm{X}$ receptor and calcium-sensing receptor, and risk of colorectal cancer in the Colon Cancer Family Registry. Carcinogenesis. 2010;31(8):1412-1416.

8. Schwartz GG, John EM, Rowland G, et al. Prostate cancer in AfricanAmerican men and polymorphism in the calcium-sensing receptor. Cancer Biol Ther. 2010;9(12):994-999.

9. Szendroi A, Speer G, Tabak A, et al. The role of vitamin D, estrogen, calcium sensing receptor genotypes and serum calcium in the pathogenesis of prostate cancer. Can J Urol. 2011;18(3):5710-5716.

10. Safaei A, Arbabi-Aval E, Arkani M, et al. Association of Calciumsensing Receptor(CASR rs1801725) with Colorectal Cancer. Zahedan Journal of Research in Medical Sciences. 2012;14(7):45-48.
11. Fedirko V, Riboli E, Tjønneland A, et al. Prediagnostic 25-hydroxyvitamin D, VDR and CASR polymorphisms, and survival in patients with colorectal cancer in western European ppulations. Cancer Epidemiol Biomarkers Prev. 2012;21(4):582-593.

12. Shui IM, Mucci LA, Wilson KM, et al. Common genetic variation of the calcium-sensing receptor and lethal prostate cancer risk. Cancer Epidemiol Biomarkers Prev. 2013;22(1):118-126.

13. Hibler EA, Hu C, Jurutka PW, Martinez ME, Jacobs ET. Cancer Epidemiol Biomarkers Prev. 2012;21(2):368-375.

14. Anderson LN, Cotterchio M, Knight JA, et al. Genetic variants in vitamin d pathway genes and risk of pancreas cancer; results from a population-based case-control study in ontario, Canada. PLoS One. 2013;8(6):e66768.

15. Kim KZ, Shin A, Kim J, et al. Association between CASR polymorphisms, calcium intake, and colorectal cancer risk. PLoS One. 2013;8(3):e59628.

16. Jorde R, Schirmer H, Njølstad I, et al. Serum calcium and the calciumsensing receptor polymorphism rs 17251221 in relation to coronary heart disease, type 2 diabetes, cancer and mortality: the Tromsø Study. Eur J Epidemiol. 2013;28(7):569-578.

17. Masvidal L, Iniesta $\mathrm{R}$, Casala $\mathrm{C}$, et al. Polymorphisms in the calciumsensing receptor gene are associated with clinical outcome of neuroblastoma. PLoS One. 2013;8(3):e59762.

18. Mahmoudi T, Karimi K, Arkani M, et al. Parathyroid hormone gene rs6256 and calcium sensing receptor gene rs1801725 variants are not associated with susceptibility to colorectal cancer in Iran. Asian Pac J Cancer Prev. 2014;15(15):6035-6039.

19. Li X, Kong X, Jiang L, et al. A Genetic Polymorphism (rs17251221) in the Calcium-Sensing Receptor is Associated with Breast Cancer Susceptibility and Prognosis. Cell Physiol Biochem. 2014;33:165-172. 
OncoTargets and Therapy

\section{Publish your work in this journal}

OncoTargets and Therapy is an international, peer-reviewed, open access journal focusing on the pathological basis of all cancers, potential targets for therapy and treatment protocols employed to improve the management of cancer patients. The journal also focuses on the impact of management programs and new therapeutic agents and protocols on

patient perspectives such as quality of life, adherence and satisfaction. The manuscript management system is completely online and includes a very quick and fair peer-review system, which is all easy to use. Visit http://www.dovepress.com/testimonials.php to read real quotes from published authors.

Submit your manuscript here: http://www.dovepress.com/oncotargets-and-therapy-journal 